\title{
PENGEMBANGAN MULTIMEDIA BERBASIS KOMPUTER UNTUK PEMBELAJARAN MATEMATIKA BAGI SISWA SMA
}

\author{
Bardi, Jailani \\ SMA Negeri 1 Mlati Sleman, Universitas Negeri Yogyakarta \\ bardi_71@yahoo.co.id, jailani@uny.ac.id
}

\begin{abstract}
Abstrak
Tujuan penelitian ini adalah menghasilkan multimedia berbasis komputer yang layak untuk pembelajaran matematika bagi siswa SMA, ditinjau dari aspek pembelajaran, aspek materi, aspek media dan persentase siswa yang mencapai ketuntasan belajar setelah menggunakan produk multimedia pembelajaran hasil pengembangan. Pengembangan multimedia pembelajaran ini dilakukan melalui tahap analisis, desain, produksi, dan uji coba. Tahap analisis meliputi menganalisis kebutuhan siswa, memilih dan menetapkan materi pokok yang akan dikembangkan, dan mengembangkan alat evaluasi. Tahap desain meliputi pembuatan storyboard dan flowchart. Tahap produksi meliputi pengemasan produk awal ke dalam bentuk CD. Tahap uji coba terdiri atas uji oleh ahli materi dan ahli media, dan uji lapangan meliputi: uji coba satu lawan satu, uji coba kelompok kecil, dan uji coba kelompok besar. Data dari hasil uji coba dikumpulkan menggunakan kuesioner dan tes, dan dianalisis dengan statistik deskriptif. Hasil uji coba digunakan untuk memperbaiki multimedia pembelajaran. Hasil penelitian menunjukkan bahwa produk multimedia pembelajaran hasil pengembangan termasuk dalam kategori "sangat baik". Persentase siswa yang mencapai ketuntasan belajar setelah menggunakan multimedia pembelajaran hasil pengembangan sebanyak $77 \%$ dan termasuk dalam kategori "baik".
\end{abstract}

Kata kunci: pengembangan multimedia berbasis komputer, pembelajaran matematika

\section{DEVELOPING COMPUTER-BASED MULTIMEDIA FOR MATHEMATICS INSTRUCTION FOR SENIOR HIGH SCHOOL STUDENTS}

Bardi, Jailani

SMA Negeri 1 Mlati, Universitas Negeri Yogyakarta bardi_71@yahoo.co.id

\begin{abstract}
This research aims to develop a feasible computer-based multimedia for mathematics instruction for senior high school students, in terms of learning, content, and media aspect and the percentage of students who master the learning material after using the developed instructional multimedia. The development of the instructional multimedia was conducted in the stages of analysis, design, production, and try out. The analysis included assessing students' needs, selecting basic material to be developed, and developing the evaluation instrument. The design included creating a storyboard and flowchart. The production included packaging the initial product into a compact disc. The try out stage consisted of feasibility judgment by experts and the field test consisted of one-to-one try out, small-group try out and large-group try out. The result of the try out was collected by a questionnaire and test, and analyzed using the descriptive statistics. The result of the try out was used to improve the multimedia. The results of the research indicate that the developed instructional multimedia is in a "very good" category. The percentage of the students who master the learning material after using the developed instructional multimedia is $77 \%$ and this is in a "good" category.
\end{abstract}

Keywords: developing computer-based multimedia, mathematics instruction 


\section{Pendahuluan}

Mata pelajaran matematika merupakan salah satu mata pelajaran yang dianggap sulit bagi siswa. Kesulitan belajar dapat diartikan sebagai suatu keadaan/ kondisi dalam proses belajar mengajar yang ditandai oleh adanya hambatanhambatan tertentu untuk mencapai hasil belajar yang baik. Namun, matematika harus diberikan di sekolah untuk semua jenjang, dengan maksud untuk membekali siswa berpikir logis, analitis, sistematis, kritis, dan kreatif, kemampuan bekerjasama. Kompetensi tersebut diperlukan agar siswa dapat memiliki kemampuan memperoleh, mengelola, dan memanfaatkan informasi untuk bertahan hidup pada keadaan yang selalu berubah, tidak pasti, dan kompetitif (Depdiknas, 2006, p.387).

Prestasi belajar matematika siswa Indonesia masih rendah, hal ini didukung fakta di lapangan yang ditunjukkan dengan rendahnya nilai matematika pada Ujian Nasional (UN) untuk jenjang SMA seperti disajikan pada Tabel 1.

Tabel 1. Nilai Rata-rata Matematika Ujian Nasional Jenjang SMA

\begin{tabular}{cccc}
\hline Tahun Pelajaran & Nasional & DIY & Sleman \\
\hline $2009 / 2010$ & 8,12 & 7,03 & 6,86 \\
$2010 / 2011$ & 8,03 & 6,49 & 6,14 \\
$2011 / 2012$ & 8,45 & 6,87 & 6,90 \\
$2012 / 2013$ & 6,07 & 6,09 & 5,84 \\
\hline
\end{tabular}

(Sumber: Pusat Penilaian Pendidikan, Balitbang Kemdikbud)

Pemanfaatan media dan konsep belajar dengan aneka sumber belum optimal. Hal ini dikarenakan (1) kurangnya pengetahuan guru tentang media, (2) terbatasnya bahkan tidak adanya sumber belajar yang memadai. Salah satu tujuan penggunaan media pembelajaran baik dalam artian sebagai alat grafis, fotografis atau elektronis adalah untuk menangkap, memproses dan menyusun informasi visual atau verbal, sedangkan proses belajar dapat dipandang sebagai aktifitas psikologis yang memerlukan dorongan dari luar.
Akibat pembelajaran yang monoton prestasi siswa sulit untuk ditingkatkan. Untuk itu perlunya mengembangkan media yang dapat merangsang siswa dapat mengikuti pelajaran dengan baik. Media yang ada di sekolah saat ini masih sangat terbatas, bahkan beberapa diantaranya kurang interaktif dalam penggunaannya. Di satu sisi, perkembangan media pembelajaran sekarang ini cukup pesat seiring berkembangnya teknologi informasi dan komunikasi.

Adapun masalah matematika dapat diklasifikasikan dalam dua jenis, yaitu: (1) soal mencari (problem to find), mencari, menentukan, atau mendapatkan nilai atau objek tertentu yang tidak diketahui dalam soal dan memenuhi kondisi atau syarat sesuai dengan soal dan (2) soal membuktikan (problem to prove), yaitu untuk menentukan apakah suatu pernyataan benar atau tidak benar.

Di sisi lain, perkembangan media pembelajaran sekarang ini tidak hanya dalam penampilannya saja, tetapi juga dalam aplikasinya sudah menggunakan gabungan beberapa atau semua media yang kita sebut sebagai "multimedia", sehingga pembelajaran menjadi lebih interaktif. Multimedia yang berbasis komputer dinilai lebih interaktif karena komputer dinilai mampu melengkapi para siswa dengan model, drill, latihan, alat referensi, sistem dan lingkungan simulasi, tes, dan perhitungan yang kompleks (Anderson, 1994, p.195).

Multimedia berbasis komputer juga memberi manfaat lain bagi siswa antara lain: (1) siswa dapat mengembangkan kemampuan berpikir lebih tinggi dan kemampuan interpersonal; (2) siswa dapat mempelajari sesuatu dengan menggabungkan beberapa disiplin ilmu; (3) siswa dapat mengembangkan kompetensi teknis dan wawasan media dalam kehidupannya (Agnew, Kellerman, \& Meyer, 1996, p.ix). Menurut Newby, Stepich, Lehman, dan Russell (2000, pp.166-170) kelebihan multimedia pembelajaran adalah penyajiannya dapat dilakukan dengan model: latihan dan praktik, tutorial, simulasi, permainan, 
dan pemecahan masalah. Dengan demikian, pembelajaran matematika menjadi lebih interaktif, menarik, dan menyenangkan.

Keunggulan pemanfaatan multimedia untuk trigonometri yang dimultimediakan adalah dapat meningkatkan motivasi belajar siswa, mampu memberikan informasi tentang skor yang dihasilkan dari megerjakan soal-soal uji kompetensi, melatih siswa untuk trampil memilih bagian isi pembelajaran yang dikehendaki, dan mendukung pembelajaran individual.

Dalam rangka meningkatkan kualitas proses pembelajaran dan menciptakan enjoyable learning untuk optimalisasi pencapaian kompetensi hasil belajar dan sebagai upaya mengatasi kelangkaan multimedia pembelajaran matematika, maka dirasa perlu mengembangkan suatu software multimedia berbasis komputer untuk pembelajaran matematika yang interaktif bagi siswa SMA.

Rumusan masalah pada penelitian ini adalah: (1) bagaimana menghasilkan multimedia berbasis komputer untuk pembelajaran matematika bagi siswa SMA? (2) Bagaimana kelayakan multimedia berbasis komputer untuk pembelajaran matematika bagi siswa SMA? (3) bagaimana hasil belajar siswa setelah menggunakan multimedia berbasis komputer untuk pembelajaran matematika bagi siswa SMA?

Adapun tujuan pengembangan pada penelitian ini adalah: (1) menghasilkan multimedia berbasis komputer untuk pembelajaran matematika bagi siswa SMA; (2) Kelayakan multimedia berbasis komputer untuk pembelajaran matematika bagi siswa SMA; (3) hasil belajar siswa setelah menggunakan multimedia berbasis komputer untuk pembelajaran matematika bagi siswa SMA.

Cara pandang terhadap proses pembelajaran berubah seiring dengan perkembangan teknologi komunikasi yang sangat pesat dewasa ini. Proses pembelajaran berlangsung tidak lagi mutlak bergantung pada tersedianya nara sumber, tempat, dan waktu belajar, tetapi juga ke- tersediaan beragam media, baik perangkat keras maupun lunak. Keberadaan media memungkinkan proses pembelajaran berlangsung sesuai kebutuhan peserta didik. Akses terhadap informasi dan ilmu pengetahuan menjadi semakin meluas bersamaan dengan berkembangnya teknologi komunikasi (Budiningsih, 2003, p.130).

Pada awalnya istilah multimedia diartikan sebagai penggunaan media lebih dari satu macam, kemudian berkembang menjadi pemanfaatan teknologi audio visual untuk pembelajaran. Namun, pada dekade ini paradigma multimedia pembelajaran telah terfokus pada interaktivitas antara media dengan pemakai media, sehingga tidak hanya diartikan sebagai penggunaan banyak media (Agnew, 1996, p.8).

Menurut Hackbarth (1996, p.229), multimedia adalah:

Multimedia is suggested as meaning the use of multiple media formats for the presentation of information, including texts, still or animated graphics, movie segments, video, and audio information. Computer based interactive nultimedia includes hypermedia and interactive linking of multimedia format information including text, still or animated graphic, movie segments, video, and audio. Hypertext is a non-linear organized and accesed sreens of text and static diagrams, pictures, and tables.

Multimedia diartikan sebagai suatu penggunaan gabungan beberapa media dalam menyampaikan informasi yang berupa teks, grafis atau animasi grafis, movie, video, dan audio. Multimedia interaktif yang berbasis komputer meliputi hypermedia dan hypertext. Hypermedia adalah suatu bentuk movie, video, daun audio. Sedangkan hypertext adalah bentuk teks, diagram statis, gambar, dan tabel yang ditayangkan dan disusun secara tidak linear.

Menurut Blackwell (diambil 22 Juli 2007) menyatakan bahwa:

Multimedia is any combination of text, graphics, art, sound, animation, and video with links and tools that let the teacher/ learner navigate, interact, and communicate 
with the computer. When you allow the user (the viever) to control what and when these elements are delivered, it is interactive multimedia.

Multimedia adalah penggabungan dari teks, grafik, gambar, animasi, dan video dengan koneksi (links) dan alat bantu (tools) sehingga pengguna dapat bernavigasi, berinteraksi, dan berkomunikasi dengan komputer. Dan ketika siswa mengontrol semua media yang ada didalamnya, hal itu yang dinamakan multimedia interaktif.

Lebih jauh multimedia diartikan oleh Vaughan:

Multimedia is the digital integration of text (written), graphics (the interface of the program), animation, audio (dialogues, stories, sound effects), still images (pictures and visual stimuli), and motion video. Through the integration of all these media, the learning experience becomes an interactive one mirroring everyday experiences.

Multimedia merupakan penggabungan digital teks (tertulis), grafik (tampilan program), animasi, audio (dialog, cerita, efek suara), gambar diam (gambar dan penarik perhatian visual) dan video yang bergerak. Melalui gabungan media-media ini pengalaman belajar menjadi sesuatu yang interaktif yang mencerminkan suatu pengalaman dalam kehidupan sehari-hari.

Oetomo (2002, p.109) menjelaskan pengertian multimedia sebagai kombinasi teks, gambar seni grafik, animasi, suara dan video yang digabungkan menjadi satu kesatuan kerja yang akan menghasilkan suatu informasi yang memiliki nilai komunikasi yang sangat tinggi; yang dapat membangkitkan selera dan memiliki nilai seni grafis yang tinggi dalam penyajiannya.

Dari beberapa pendapat di atas dapat ditarik kesimpulan bahwa multimedia merupakan suatu gabungan antara teks, gambar, grafis, animasi, audio dan video, serta cara penyampaian interaktif yang dapat membuat suatu pengalaman belajar bagi siswa seperti dalam kehidupan nyata di sekitarnya.
Dalam pembelajaran, peranan multimedia berbasis komputer menjadi semakin penting di masa sekarang, karena sistem multimedia yang terdiri dari komponen media-media (teks, gambar, grafis, animasi, audio dan video) tersebut dirancang untuk saling melengkapi sehingga menjadi suatu sistem yang berdaya guna dan tepat guna, suatu kesatuan menjadi lebih baik daripada jumlah bagian-bagiannya. Penggunaan multimedia berbasis komputer dapat diterima dalam pembelajaran atas dasar mempertinggi proses belajar mandiri serta peran aktif dari siswa. Sistem multimedia berbasis komputer juga memberikan rangsangan bagi proses pembelajaran yang berlangsung di luar ruang kelas.

Selanjutnya, peran multimedia berbasis komputer dalam pembelajaran adalah dapat memberikan jawaban atas suatu bentuk pembelajaran yang dulunya secara tradisional belum dapat dilaksanakan. Hal ini di diperkuat oleh pendapat Agnew, Kellerman \& Meyer (1996, p.6) bahwa:

Where as some applications use computers merely to facilitate activities that students could perform in other ways, multimedia uses computers to help students perform activities that were previously impossible. A word processor makes a typewriter that can change and reformat pages, and a spreadsheet makes a sheet of squared paper that recalculates numbers, so either just makes a function that was already possible go faster and easier. However, the links that are a key part of multimedia projects allow users to interact with information in completely new ways.

Ketika pembelajaran dengan menggunakan komputer hanya bertujuan agar pebelajar mendapatkan suasana lain, multimedia yang menggunakan komputer dapat membantu pebelajar melakukan aktivitas pelatihan yang dulunya tidak mungkin dapat dilaksanakan. Suatu "word processor" membuat suatu mesin ketik yang dapat mengubah dan memformat kembali halaman-halaman yang diinginkan, dan 
"spreadsheet" membuat sebuah kertas tabel yang dapat menghitung angka-angka, dan juga membuat kegunaannya menjadi memungkinkan bekerja lebih cepat dan mudah. Bagaimanapun juga, penggunaan "link" (jaringan) merupakan bagian penting dalam multimedia yang membuat para pebelajar dapat berinteraksi dengan informasi-informasi yang ada dengan cara yang benar-benar baru.

Jadi, jelas sekali bahwa penggunaan multimedia berbasis komputer dalam pembelajaran akan membuat pembelajaran lebih interaktif terutama dengan penggunaan "link" yang memungkinkan pembelajar belajar sesuai dengan yang diinginkan.

Penggunaan multimedia pembelajaran berbasis komputer juga dapat membuat pembelajar lebih mengingat materi yang dipelajari. Hal ini sesuai dengan hasil riset dari Computer Technology Reaserch tahun 1993 bahwa "Seseorang hanya dapat mengingat apa yang dia lihat sebesar $20 \%$, dan apa yang dia dengar sebesar $30 \%$, apa yang dia dengar dan lihat sebesar $50 \%$, dan sebesar $80 \%$ dari apa yang dia lihat, dengar, dan kerjakan secara simultan. Pencapaian $80 \%$ tersebut sangat dimungkinkan dapat dicapai dengan menggunakan multimedia pembelajaran berbasis komputer yang interaktif (Dwi Priyanto, 2009, p.4).

Hal ini diperjelas pendapat Blackwell bahwa:

Multimedia lets the teacher/learner navigate, interact, and communicate with the computer. When you allow the user (the viewer) to control what and when these elements are delivered, it is interactive multimedia.

Multimedia membiarkan pembelajar menggunakan tombol-tombol yang tersedia, berinteraksi, dan berkomunikasi dengan komputer. Dan ketika pebelajar mengontrol semua media yang ada di dalamnya, itulah yang dinamakan multimedia yang interaktif. Jadi, dengan penggunaan multimedia pembelajaran berbasis komputer yang interaktif, mahasiswa tidak hanya melihat dan mendengar, tetapi juga mengerjakan perintah-perintah di dalamnya secara simultan.

Pengembangan multimedia pembelajaran termasuk dalam domain "pengembangan" dalam kawasan teknologi pembelajaran. Seels \& Richey (1994, p.9), mengemukakan bahwa insructional technology is the theory and practice of design, development, utilization, management, evaluation of processes, and resources for learning. Dapat dijelaskan bahwa definisi teknologi pembelajaran adalah teori dan praktik desain, pengembangan, pemakaian, managemen dan evaluasi proses dan sumber untuk belajar. Dari definisi ini terdapat empat komponen penting yaitu: (1) teori dan praktik, (2) desain, pengembangan, pemakaian, managemen, dan evaluasi, (3) proses dan sumber, dan (4) untuk belajar.

Dalam domain pengembangan terdapat empat kategori didalamnya yaitu teknologi cetak (yang mendasari teknologi lain), teknologi audiovisual, teknologi berbasis komputer dan teknologi terpadu (Seels \& Richey, 1994, p.26).

Teknologi cetak adalah cara-cara untuk memproduksi atau menyebarkan materi, seperti buku dan materi visual statis, yang pada umumnya dilakukan melalui proses cetak mekanis atau fotografi. Secara spesifik, teknologi cetak/visual memiliki karekteristik sebagai berikut: (1) teks dibaca secara linear, sedangkan visual disajikan secara spasial, (2) keduanya merupakan media satu arah, yaitu komuniksi reseptif, (3) keduanya merupakan visual statis, (4) pengembangan keduanya tergantung pada prinsip-prinsip kebahasaan dan persepsi visual, (5) keduanya berpusat pada pembelajar, dan (6) informasi dapat diorganisasi dan ditata lagi oleh pemakai.

Teknologi audiovisual adalah caracara untuk memproduksi atau menyebarkan materi dengan menggunakan mesin mekanis atau elektronik untuk menyajikan pesan auditori dan visual. Secara spesifik, teknologi audiovisual cenderung memiliki karakteristik sebagai berikut: (1) bersifat linear; (2) menyajikan visual dinamis; (3) digunakan dalam cara yang sudah ditentu- 
kan oleh desainer atau pengembang; (4) cenderung menyajikan konsep real dan abstrak secara fisik; (5) dikembangkan menurut psikologi behavioral dan psikologi kognitif; dan (6) sering berpusat pada guru dan tidak banyak melibatkan siswa secara interaktif.

Teknologi berbasis komputer adalah cara-cara untuk menggunakan sumbersumber yang didasarkan pada mikroprosesor. Karakteristik dari teknologi berbasis komputer adalah (1) dapat digunakan secara acak atau tidak urut, maupun secara linear; (2) dapat digunakan sesuai dengan kemauan pembelajar, maupun dalam cara yang drencanakan oleh desainer; (3) konsep-konsepnya pada umumnya disajikan dalam gaya abstrak dengan kata-kata, simbol, dan grafik; (4) prinsip ilmu pengetahuan kognitif diterapkan selama pengembangannya, dan (5) belajarnya dapat berpusat pada siswa dan menghendaki kegiatan pembelajar secara interaktif.

Teknologi terpadu adalah cara-cara memproduksi dan menyebarkan materi yang mengandung beberapa bentuk media dengan panduan komputer. Karakteristik pembelajaran dengan teknologi terpadu adalah: (1) dapat digunakan secara acak atau tidak urut, maupun secara linear; (2) dapat digunakan sesuai dengan cara yang dikehendaki oleh pembelajar, tidak hanya cara yang direncanakan desainer; (3) konsep-konsep disajikan secara realistik dalam konteks pengalaman pembelajar, dan di bawah kendali pembelajar; dan (4) prinsipprinsip ilmu pengetahuan kognitif dan konstruktif.

Kesimpulan dari uraian tersebut bahwa pengembangan media pembelajaran berbasis komputer merupakan kegiatan pemanfaatan teknologi pembelajaran khususnya fungsi pengembangan sumber belajar melalui tahap-tahap mengidentifikasi, mengembangkan, dan mengevaluasi materi dan strategi hingga menghasilkan sebuah produk berupa CD pembelajaran interaktif. Dengan demikian, hambatan belajar terutama yang berkaitan dengan keterbatasan sumber belajar diharapkan dapat teratasi, karena CD pembelajaran interaktif merupakan salah satu sumber belajar yang dapat digunakan secara mandiri oleh siswa.

Beberapa hasil penelitian yang mendukung berhasilnya pembelajaran dengan multimedia berbasis komputer adalah sebagai berikut. Pertama, hasil penelitian Woolf \& Hall tahun 1995 (diambil tanggal 20 September 2005 dari http://ckc.cs. umass.edu/ckc/publications/multimedia pedagogues.pdf) yang berjudul "Interactive multimedia systems for teaching and learning" menunjukkan bahwa pembelajaran multimedia berbasis komputer lebih efektif dan dapat memberikan pengalaman yang berkualitas dibandingkan pengajaran yang tradisional.

Kedua, hasil penelitian Jenks tahun 2002 (diambil pada tanggal 19 Agustus 2007 dari http://ejite.isu.edu/Volume1 No2/Jenks.pdf) yang berjudul "A view of the research of efficacy of CAI" menunjukkan bahwa pemberian remedial dengan komputer lebih efektif dibandingkan dengan remedial yang tidak menggunakan komputer.

Ketiga, hasil penelitian yang dilakukan oleh Kulik, Bangert, \& Williams tahun 83 (Electronic Journal for the Integration of Technology in Education, Vol. 1 no. 2:2002) menganalisis 48 penelitian tentang pengaruh pembelajaran dengan komputer pada siswa Sekolah Menengah dalam bidang studi Matematika dan IPA. 39 dari 48 penelitian melaporkan bahwa pembelajaran dengan komputer mendapatkan skor yang lebih baik dalam ujian akhir dibanding dengan pembelajaran secara konvensional.

Keempat, hasil penelitian Ayres (2002) untuk mengetahui sikap siswa terhadap pembelajaran berbantuan komputer. Penelitian dilakukan terhadap 157 siswa yang berasal dari 27 negara di School of English and Applied Linguistics. Hasil penelitian menunjukkan bahwa $80 \%$ siswa memandang pembelajaran bahasa berbantuan komputer relevan dengan kebutuhan mereka, 77\% siswa mengatakan bahwa tugastugas berbasis komputer mennyediakan 
informasi yang berguna bagi mereka, dan $60 \%$ siswa menyetujui apabila pembelajaran berbantuan komputer sering digunakan. Gunn (1997) mengadakan penelitian untuk mengetahui seberapa jauh manfaat penggunaan multimedia interaktif bagi siswa kursus dengan subjek penelitian 129 siswa.

Kelima, hasil penelitian Klassen \& Drummond (Gafur, 2004, p.16) tentang manfaat multimedia interaktif untuk perkuliahan Simulasi Bisnis menemukan bahwa mahasiswa merasa senang dan termotivasi dengan penggunaan multimedia tersebut. Selain itu penggunaan multimedia lebih memberikan kejelasan bila dibandingkan dengan pengajaran secara tradisional.

Dari beberapa penelitian tersebut dapat disimpulkan bahwa pembelajaran yang menggunakan komputer atau multimedia dapat menghasilkan skor yang lebih baik, dapat lebih efektif, dapat lebih menarik, dapat lebih memotivasi siswa, dapat memberikan pengalaman yang berkualitas bagi peserta didik dibanding dengan pembelajaran yang konvensional.

\section{Metode Penelitian}

\section{Model Pengembangan}

Penelitian pengembangan merupakan suatu jenis penelitian yang tidak dimaksudkan untuk menguji teori, akan tetapi merupakan penelitian yang berorientasi untuk menghasilkan atau mengembangkan dan memvalidasi sebuah produk. Menurut Borg \& Gall (1983, p.772), penelitian dan pengembangan pendidikan (education research and development) adalah proses yang digunakan untuk mengembangkan dan memvalidasi produk-produk pendidikan, yang bukan hanya bersifat materi seperti buku teks, film pembelajaran, dan lain-lain, tetapi juga termasuk prosedur dan proses, seperti metode pembelajaran atau metode pengelolaan pembelajaran.

Model ADDIE memiliki lima tahap pengembangan sebagai berikut. Pertama adalah langkah analisis. Langkah analisis terdiri atas dua tahap, yaitu analisis kinerja dan analisis kebutuhan. Tahap pertama adalah analisis kinerja yang dilakukan untuk mengetahui dan mengklarifikasi apakah masalah kinerja yang dihadapi memerlukan solusi berupa penyelenggaraan program pembelajaran. Tahap kedua adalah analisis kebutuhan yang diperlukan untuk menentukan kemampuan-kemampuan atau kompetensi yang perlu dipelajari oleh siswa untuk meningkatkan prestasi belajar.

Langkah kedua adalah desain. Pada langkah ini diperlukan adanya klarifikasi program pembelajaran yang didesain sehingga program tersebut dapat mencapai tujuan pembelajaran seperti yang diharapkan. Pada langkah desain, pusat perhatian perlu difokuskan pada upaya untuk menyelidiki masalah pembelajaran yang sedang dihadapi. Hal ini merupakan inti dari langkah analisis, yaitu mempelajari masalah dan menemukan alternatif solusi yang akan ditempuh untuk dapat mengatasi masalah pembelajaran yang berhasil diidentifikasi melalui langkah analisis kebutuhan. Langkah penting yang perlu dilakukan dalam desain adalah menentukan pengalaman belajar yang perlu dimiliki oleh siswa selama mengikuti aktivitas pembelajaran. Langkah desain harus mampu menjawab pertanyaan apakah program pembelajaran yang didesain dapat digunakan untuk mengatasi masalah kesenjangan performa yang terjadi pada diri siswa.

Ketiga adalah langkah pengembangan. Langkah pengembangan meliputi kegiatan membuat dan memodifikasi bahan ajar untuk mencapai tujuan pembelajaran yang telah ditentukan. Pengadaan bahan ajar perlu disesuaikan dengan tujuan pembelajaran spesifik yang telah dirumuskan oleh perancang program pembelajaran dalam langkah desain. Langkah pengembangan, dengan kata lain, mencakup kegiatan memilih dan menentukan metode, media, serta strategi pembelajaran yang sesuai untuk digunakan dalam menyampaikan materi atau substansi program pembelajaran. 
Keempat adalah langkah implementasi. Implementasi atau penyampaian materi pembelajaran merupakan langkah keempat dari model desian sistem pembelajaran ADDIE. Langkah implementasi sering diasosiasikan dengan penyelenggaraan program pembelajaran itu sendiri. Langkah ini memang mempunyai makna adanya penyampaian materi pembelajaran dari guru kepada siswa.

Kelima adalah langkah evaluasi. Evaluasi dapat didefinisikan sebagai sebuah proses yang dilakukan untuk memberikan nilai terhadap program pembelajaran. Pada dasarnya, evaluasi dapat dilakukan sepanjang pelaksanaan kelima langkah dalam model ADDIE. Pada langkah analisis misalnya, proses evaluasi dilaksanakan dengan cara melakukan klarifikasi terhadap kompetensi pengetahuan, keterampilan dan sikap yang harus dimiliki oleh siswa setelah mengikuti program pembelajaran. Evaluasi seperti ini dikenal dengan istilah evaluasi formatif.

Model pengembangan tersebut dapat dilihat pada gambar berikut ini.

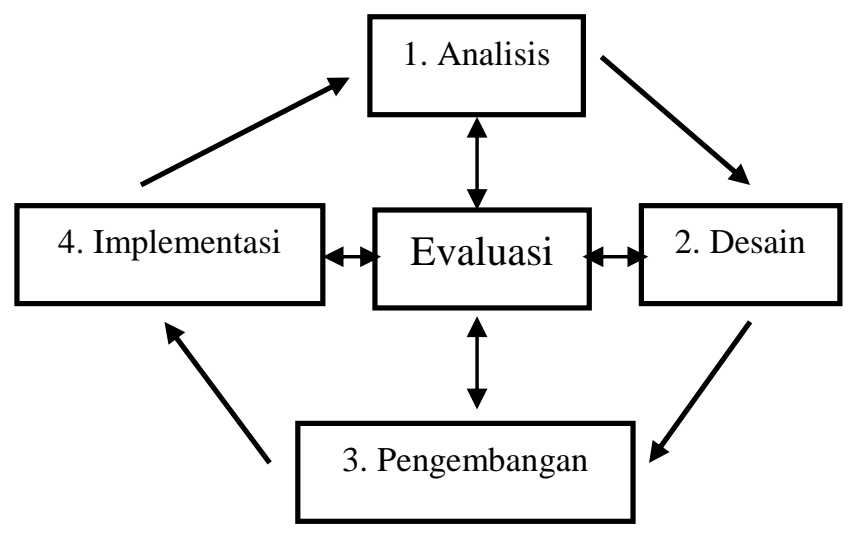

(Diadaptasi dari Model ADDIE)

Gambar 1. Model Pengembangan Multimedia

Prosedur Pengembangan

Berdasarkan adaptasi model pengembangan multimedia pembelajaran dan untuk dapat menghasilkan suatu produk yang valid dan berkualitas maka beberapa prosedur pengembangan dalam penelitian sebagai berikut: Pertama adalah tahap analisis, meliputi: (1) menganalisis kebutuhan dan karakteristik siswa; (2) mengkaji kurikulum, kemudian memilih dan menetapkan standar kompetensi dan kompetensi dasar; (3) merumuskan materi pembelajaran, merumuskan strategi pembelajaran, merumuskan evaluasi formatif; (4) menetapkan jenis aplikasi multimedia, dipilih multimedia interaktif; layout dasar; (6) pemilihan warna dan jenis font; (6) sistem distribusi multimedia, dipilih menggunakan CD; dan sistem operasi yang digunakan oleh user agar dapat menjalankan multimedia.

Kedua adalah tahap design dan pengembangan. Pada tahap ini dilakukan 3 langkah, yaitu: (a) mengembangkan flowchart; (b) menentukan storyboard; (c) mengumpulkan semua materi yang dibutuhkan dalam membuat produk multimedia pembelajaran. Mengemas produk awal multimedia pembelajaran kedalam $C D$ pembelajaran yang interaktif, padu, dan menarik.

Ketiga adalah melakukan uji kelayakan terbatas kepada satu ahli materi dan satu ahli media. Keempat, setelah menganalisis hasil uji kelayakan terbatas dari ahli materi dan ahli media dan merevisi produk berdasarkan hasil uji kelayakan terbatas tersebut, dilakukan uji coba satu lawan satu kepada 3 siswa dan meminta penilaiannya melalui kuesioner. Kelima, setelah menganalisis hasil penilaian siswa dan melakukan revisi produk berdasarkan penilaian siswa pada uji coba satu lawan satu, dilakukan uji coba kelompok kecil kepada 12 siswa untuk menguji tingkat kualitas produk yang lebih mendalam dengan meminta penilaiannya melalui kuesioner.

Keenam, setelah menganalisis hasil penilaian siswa dan melaku-kan revisi produk berdasarkan penilaian siswa pada uji coba kelompok kecil, dilakukan uji coba lapangan kepada 30 siswa untuk menguji tingkat kualitas produk yang lebih mendalam dan meminta penilaiannya tentang kualitas multimedia tersebut melalui kuesioner. Ketujuh, setelah menganalisis hasil penilaian siswa dan melakukan revisi pro- 
duk berdasarkan penilaian siswa, dilakukan pembuatan produk akhir.

Desain Uji Coba Produk

Sebelum dimanfaatkan secara umum CD pembelajaran perlu dilakukan uji coba terlebih dahulu. Uji coba produk dimaksudkan untuk mengumpulkan data tentang kualitas multimedia berbasis komputer yang dikembangkan dalam rangka untuk mencapai suatu tujuan pembelajaran matematika, dari aspek pembelajaran, materi, dan media. Data-data yang diperoleh digunakan untuk memperbaiki dan menyempurnakan produk multimedia berbasis komputer dalam pembelajaran matematika, yang dikembangkan dalam penelitian ini. Dengan uji coba produk, diharapkan bahwa kualitas produk multimedia yang dikembangkan dapat teruji baik secara empiris maupun secara teoritis.

Produk yang akan diujicobakan terlebih dahulu diuji kelayakannya oleh satu ahli materi dan satu ahli media. Uji kelayakan ini penting dilakukan untuk mengantisipasi materi-materi yang dibutuhkan, bantuan para ahli di bidangnya, dan situasi uji lapangan. Pertimbangan waktu dan karakteristik siswa dalam uji lapangan perlu dilakukan supaya hasilnya sesuai dengan yang diharapkan. Penilaian, komentar dan saran para ahli dibidangnya sangat diperlukan supaya produk yang dikembangkan tidak mengalami banyak kesalahan, sesuai dengan yang dibutuhkan, dan tidak menghabiskan waktu, tenaga dan biaya yang sia-sia. Dalam uji kelayakan produk, ahli materi memberikan penilaian, komentar dan saran pada produk dan instrumen penelitian dari aspek pembelajaran dan aspek materi. Ahli media memberikan penilaian pada produk dan instrumen penelitian dari aspek media. Data hasil review ahli materi dan ahli media dijadikan pedoman dalam perbaikan multimedia.

Ada tiga tahapan uji coba yang dilakukan dalam pengembangan ini yaitu: uji coba satu lawan satu; uji coba kelompok kecil; uji coba lapangan.
Subjek Coba

Subjek uji coba pada penelitian ini adalah siswa kelas $X$ di SMA Negeri 1 Mlati pada tahun pelajaran 2007/2008. Pemilihan subjek uji coba dilakukan dengan mempertimbangkan karakteristik siswa, dipilih dari siswa yang mempunyai kemampuan rata-rata tinggi, sedang, dan di bawah rata-rata.

Untuk uji kelayakan terbatas produk multimedia yang dikembangkan dari aspek pembelajaran dan materi, dipilih satu orang ahli materi dari dosen Program Studi Matematika Universitas Negeri Yogyakarta. Untuk uji kelayakan terbatas produk multimedia yang dikembangkan dari aspek media, dipilih satu ahli media dari Fakultas Pascasarjana Universitas Negeri Yogyakarta.

\section{Teknik dan Instrumen Pengumpulan Data}

Tujuan penelitian ini adalah mendeskripsikan kualitas multimedia Matematika yang dikembangkan. Untuk mengetahui kualitas produk multimedia berbasis komputer hasil pengembangan, ditinjau dari tiga aspek yaitu: aspek pembelajaran, materi, dan media. Data yang dikumpulkan yaitu data kuantitatif yang berupa skor tanggapan siswa terhadap multimedia berbasis komputer hasil pengembangan melalui angket dan nilai siswa pada evaluasi (uji kompetensi).

Instrumen dalam penelitian digunakan untuk mengetahui kualitas multimedia pembelajaran matematika bagi siswa SMA kelas $X$ dari aspek pembelajaran, materi, dan media sehingga pengukurannya digunakan instrumen yang berupa kuesioner. Kuesioner digunakan untuk mengukur kualitas multimedia pembelajaran yang dikembangkan, dari aspek pembelajaran, materi, dan media. Uji kompetensi digunakan untuk mengetahui jumlah persentase siswa yang sudah mencapai ketuntasan belajar, setelah menggunakan multimedia pembelajaran hasil pengembangan. 
Teknik Analisis Data

Data mengenai pendapat/tanggapan siswa yang dikumpulkan melalui kuesioner dianalisis dengan statistik deskriptif. Hasil angket dianalisis dengan kriteria sebagai berikut:

Angka 5 = sangat baik

Angka $4=$ baik

Angka $3=$ cukup

Angka 2 = kurang baik

Angka 1= sangat kurang baik

Untuk skor yang diperoleh, dikonversikan menjadi nilai, pada skala 5 (Sukardjo, 2005, p.55) yang disajikan pada Tabel 2.

Tabel 2. Konversi Skor ke Nilai pada Skala 5

\begin{tabular}{ccc}
\hline Interval skor & Nilai & Kategori \\
\hline $\mathrm{x}>\bar{X}_{\mathrm{i}+1,80 \mathrm{SBi}}$ & $\mathrm{A}$ & Sangat Baik \\
$\bar{X}_{\mathrm{i}}+0,60 \mathrm{SBi}<\mathrm{X} \leq \bar{X}_{\mathrm{i}}+1,80 \mathrm{SBi}$ & $\mathrm{B}$ & Baik \\
$\bar{X}_{\mathrm{i}-0,60 \mathrm{SBi}<\mathrm{X} \leq \bar{X}_{\mathrm{i}}+0,60 \mathrm{SBi}}$ & $\mathrm{C}$ & Cukup Baik \\
$\bar{X}_{\mathrm{i}-1,80 \mathrm{SBi}<\mathrm{X} \leq \bar{X}_{\mathrm{i}-0,60 \mathrm{SBi}}} \mathrm{D}$ & Kurang Baik \\
$\mathrm{X} \leq \bar{X}_{\mathrm{i}}-1,80 \mathrm{SBi}$ & $\mathrm{E}$ & Sangat Kurang \\
\hline
\end{tabular}

Keterangan :

$\bar{X}_{\mathrm{i}}=$ Rerata ideal $=\frac{1}{2}$ (skor maksimal ideal + skor minimal ideal)

$\mathrm{SBi}=$ Simpangan baku ideal $=\frac{1}{6}$ (skor maksimal ideal - skor minimal ideal)

$\mathrm{X}=$ Skor siswa hasil uji coba

Berdasarkan rumus konversi pada Tabel 2, dapat diperoleh gambaran yang jelas dalam mengubah data kuantitatif menjadi data kualitatif. Pedoman pengubahan data kuantitatif menjadi data kualitatif yang disajikan pada Tabel 3.

Dengan demikian, skor tiap butir tanggapan yang diperoleh dapat dikonversikan menjadi nilai untuk mengetahui kategori setiap butir tanggapan atau ratarata secara keseluruhan terhadap multimedia pembelajaran hasil pengembangan. Dengan berpedoman pada Tabel 3 di atas, akan lebih mudah untuk memberikan suatu kriteria nilai bahwa multimedia pem- belajaran hasil pengembangan, sudah layak atau belum digunakan dalam kegiatan pembelajaran, baik dari aspek pembelajaran, aspek materi maupun aspek media.

Tabel 3. Pedoman Pengubahan Data Kuantitatif menjadi Data Kualitatif

\begin{tabular}{ccc}
\hline \multicolumn{1}{c}{ Interval Skor } & Nilai & Kategori \\
\hline$X>4,21$ & A & Sangat Baik \\
$3,40<X \leq 4,21$ & B & Baik \\
$2,60<X \leq 3,40$ & C & Cukup Baik \\
$1,79<X \leq 2,60$ & D & Kurang Baik \\
$X \leq 1,79$ & E & Sangat Kurang Baik \\
\hline
\end{tabular}

Keterangan :

Skor maksimal $=5$ perbutir

Skor minimal $=1$ perbutir

$\bar{X}_{\mathrm{i}}=\frac{1}{2}$ (skor maksimal ideal + skor minimal ideal) $=\frac{1}{2}(5+1)=3$

$\mathrm{SBi}=$ Simpangan baku ideal $=\frac{1}{6}$ (skor maksimal ideal - skor minimal ideal)

$=\frac{1}{6}(5-1)=0,67$

$\mathrm{X}=$ Skor aktual

Pada penelitian pengembangan ini, peneliti memberi nilai kelayakan produk multimedia pembelajaran hasil pengembangan minimal " $\mathrm{B}$ " dengan kategori "Baik", sehingga hasil penilaian, baik dari ahli materi, ahli media maupun siswa, jika sudah memberikan hasil penilaian akhir (keseluruhan) dengan nilai minimal " $B$ " (Baik), maka produk multimedia pembelajaran hasil pengembangan tersebut sudah dianggap layak digunakan.

\section{Hasil dan Pembahasan}

Hasil Uji Coba Terbatas

\section{Ahli Materi}

Ahli materi dalam produk penelitian ini adalah Edi Prajitno, M.Pd. Beliau adalah dosen Jurusan Pendidikan Matematika pada FMIPA Universitas Negeri Yogyakarta. Penilaian yang dilakukan oleh ahli materi terhadap multimedia pembelajaran hasil pengembangan terdiri aspek pembelajaran dan aspek materi. Penilaian oleh ahli 
materi tersebut dilakukan dengan menggunakan kuesioner. Untuk memperoleh produk multimedia yang layak, ahli materi juga memberikan komentar dan saransaran.

Ahli materi memberikan penilaian dari aspek pembelajaran dan aspek materi termasuk kategori baik. Skor rata-rata untuk aspek pembelajaran 3,88 dengan kategori baik dan skor rata-rata untuk aspek materi 4,00 dengan kategori baik. Rata-rata skor keseluruhan dari aspek pembelajaran dan aspek materi yaitu: 3,93 setelah dikonversikan ke skala 5 termasuk kriteria " Baik".

\section{Ahli Media}

Ahli media dalam produk penelitian ini adalah Herman Dwi Surjono, Ph.D. Beliau adalah Kaprodi Teknologi Pembelajaran Program Pascasarjana Universitas Negeri Yogyakarta. Data yang diperoleh dari hasil penilaian ahli media terhadap multimedia pembelajaran hasil pengembangan, hanya satu aspek yaitu aspek media. Penilaian oleh ahli media tersebut dilakukan dengan menggunakan kuesioner. Untuk memperoleh produk multimedia yang layak, ahli media memberikan saran-saran.

Hasil analisis data penilaian dari ahli media diperoleh skor total untuk aspek media 80 dan skor rata-ratanya 3,81 setelah dikonversikan ke skala 5 termasuk kategori "Baik".

\section{Hasil Uji Coba Satu Lawan Satu}

Setelah produk multimedia dilakukan uji kelayakan oleh ahli materi dan ahli media, kemudian dilakukan uji coba satu lawan satu kepada siswa SMA Negeri 1 Mlati. Uji coba ini diikuti siswa sebanyak 3 orang. Data yang diperoleh dari uji coba ini digunakan sebagai dasar untuk melakukan revisi produk sebelum digunakan pada uji coba kelompok kecil.

Ada tiga aspek yang dianalisis pada uji coba satu lawan satu, yaitu: aspek pembelajaran, aspek materi, dan aspek media. Skor rata-rata untuk aspek pembelajaran 4,28 setelah dikonversikan pada skala 5 berarti termasuk kategori "Sangat Baik". Skor rata-rata untuk aspek materi 4,25 setelah dikonversikan pada skala 5 berarti termasuk kategori "Sangat Baik", dan skor rata-rata aspek media 4,17 setelah dikonversikan pada skala 5 berarti termasuk kategori "Baik". Skor rata-rata keseluruhan untuk aspek pembelajaran, aspek materi, dan aspek media adalah 4,23 setelah dikonversikan pada skala 5 berarti termasuk kategori "Sangat Baik".

Berdasarkan hasil analisis uji coba satu lawan satu, dapat dikatakan bahwa produk multimedia pembelajaran matematika hasil pengembangan ditinjau dari aspek pembelajaran, aspek materi maupun aspek media mendapat nilai " $A$ " termasuk dalam kategori "Sangat Baik", sehingga layak untuk digunakan pada uji coba kelompok kecil.

\section{Hasil Uji Coba Kelompok Kecil}

Uji coba kelompok kecil diberikan kepada 12 siswa kelas X SMA Negeri 2 Mlati. Penentuan responden pada uji coba ini dilakukan oleh guru yang mengajar kelas X di SMA tersebut. Data diperoleh melalui kuesioner dan deskripsi tanggapan siswa.

Selain memberikan tanggapan terhadap multimedia pembelajaran hasil pengembangan, responden juga memberikan komentar yang ditulis pada kuesioner yang diberikan. Berikut komentar menurut responden pada uji coba kelompok kecil: penggunaan media menarik dan menambah motivasi belajar, penggunaan media memudahkan siswa dalam memahami materi yang dipelajari.

Ada tiga aspek yang dianalisis pada uji coba kelompok kecil, yaitu: aspek pembelajaran, aspek materi, dan aspek media. Skor rata-rata untuk aspek pembelajaran 4,23 setelah dikonversikan pada skala 5 berarti termasuk kategori "Sangat Baik". Skor rata-rata untuk aspek materi 4,27 setelah dikonversikan pada skala 5 
berarti termasuk kategori "Sangat Baik", dan skor rata-rata aspek media 4,13 setelah dikonversikan pada skala 5 berarti termasuk kategori "Baik". Skor rata-rata keseluruhan untuk aspek pembelajaran, aspek materi, dan aspek media adalah 4,20 setelah dikonversikan pada skala 5 berarti termasuk kategori "Baik".

Berdasarkan hasil analisis uji coba kelompok kecil, dapat dikatakan bahwa produk multimedia pembelajaran matematika hasil pengembangan ditinjau dari aspek pembelajaran, aspek materi maupun aspek media mendapat nilai " $B$ " termasuk dalam kategori "Baik", sehingga layak untuk digunakan pada uji coba kelompok besar.

\section{Hasil Uji Coba Kelompok Besar}

Siswa memberikan tanggapan terhadap multimedia pembelajaran hasil pengembangan, responden juga memberikan komentar dan saran yang ditulis pada kuesioner yang diberikan. Berikut sebagian komentar dan saran menurut responden pada uji coba kelompok besar: penjelasan soal sangat baik dan efisien, dapat mendorong motivasi siswa supaya lebih giat dalam belajar; sangat senang dengan program ini, karena dengan program ini siswa lebih mudah memahami materi pelajaran dan sebaiknya program ini disebarluaskan ke masyarakat agar dapat dimanfaatkan; Pembelajaran seperti ini membuat siswa tidak mudah bosan dan program ini sebaiknya dikenalkan kepada semua siswa; sangat efisien, karena contoh soal yang diberikan dapat membantu dalam proses belajar dan siswa lebih mudah untuk memahaminya.

Uji coba kelompok besar diberikan kepada 30 siswa kelas X SMA Negeri 1 pada tanggal 10 Juni 2008. Data terdiri dari tiga aspek, yaitu aspek pembelajaran, aspek materi, dan aspek media yang diperoleh melalui koesioner.

Data tanggapan siswa dari aspek pembelajaran diperoleh skor pada setiap butir peryataan termasuk dalam kategori baik dan sangat baik. Jumlah skor rata-rata 80,07 dan rata-rata skor keseluruhan 4,45 dengan kategori sangat baik.

Persentase tanggapan siswa dalam uji coba kelompok besar dari aspek pembelajaran, disajikan dalam Gambar 2.

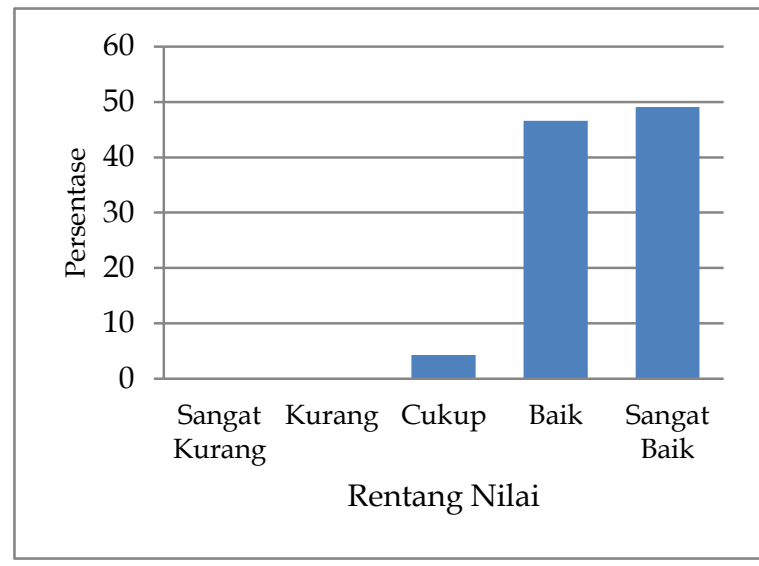

Gambar 2. Persentase Aspek

Pembelajaran

Data tanggapan siswa pada uji coba kelompok besar dari aspek materi diperoleh skor jumlah skor rata-rata 53,70 dan rata-rata skor keseluruhan 4,48 setelah dikonversikan pada skala 5 termasuk kategori "Sangat Baik".

Persentase tanggapan siswa dalam uji coba kelompok besar dari aspek materi, disajikan dalam Gambar 3.

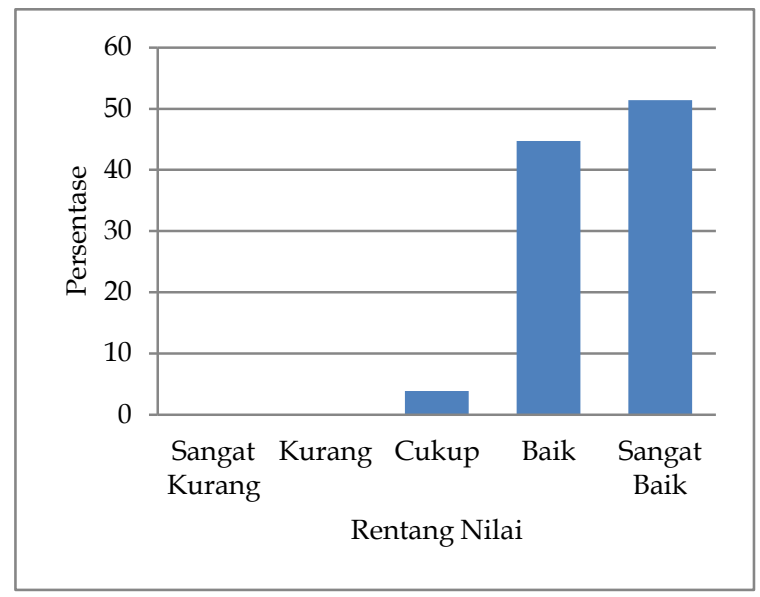

Gambar 3. Persentase Aspek Materi

Data tanggapan siswa pada uji coba kelompok besar dari aspek media diperoleh skor jumlah skor rata-rata 79,53 dan rata-rata skor keseluruhan 4,42 setelah 
dikonversikan pada skala 5 termasuk kategori "Sangat Baik".

Persentase tanggapan siswa dalam uji coba kelompok besar dari aspek media, disajikan dalam Gambar 4.

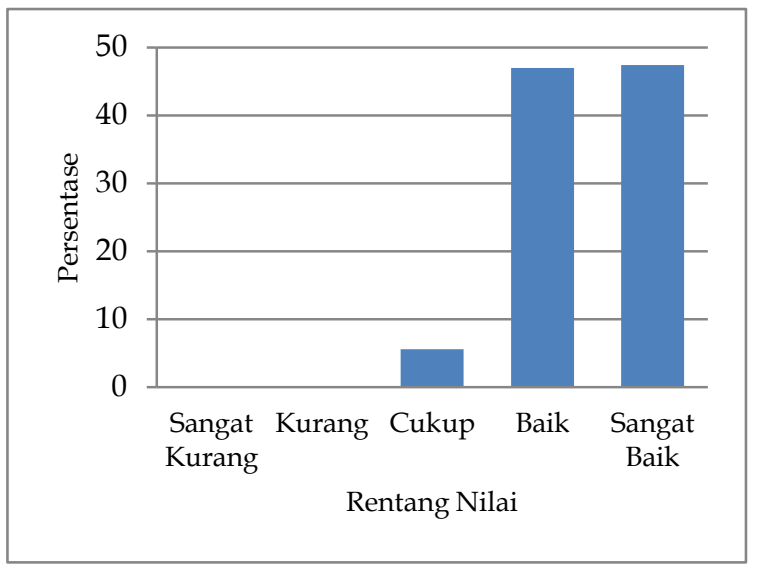

Gambar 4. Persentase Aspek Media

Dari hasil analisis data uji coba kelompok besar, dapat dikatakan bahwa produk multimedia pembelajaran matematika hasil pengembangan ditinjau dari aspek pembelajaran, aspek materi maupun aspek media mendapat nilai " $\mathrm{A}$ " termasuk dalam kategori "Sangat Baik". Hal itu menunjukkan bahwa produk multimedia pembelajaran hasil pengmbangan tersebut layak digunakan untuk pembelajaran.

\section{Hasil Uji Kompetensi}

Uji kompetensi adalah proses yang dilakukan untuk mengukur pencapaian kompetensi siswa secara berkelanjutan dalam proses pembelajaran, untuk memantau kemajuan, melakukan perbaikan pembelajaran, dan menentukan keberhasilan belajar siswa. Pencapaian kompetensi seorang siswa dapat dilihat dari keberhasilan siswa tersebut dalam mencapai nilai KKM (Kriteria Ketuntasan Mimimal). Untuk KKM mata pelajaran matematika kelas $X$ di SMA Negeri 1 Mlati tahun pelajaran 2007/ 2008 ditetapkan sebesar "60". Sehingga, apabila seorang siswa mendapat nilai $\geq 60$ dikatakan telah mencapai ketuntasan belajar.

Hasil uji kompetensi yang dilakukan oleh peserta uji coba kelompok besar setelah dilaksanakan pembelajaran dengan multimedia pembelajaran matematika hasil pengembangan diperoleh bahwa sebanyak 77\% siswa mencapai ketuntasan, dengan skor rata-rata 71,33 termasuk kategori "Baik".

Hasil analisis data pada uji coba kelompok besar menunjukkan bahwa penilaian terhadap produk multimedia pembelajaran hasil pengembangan pada aspek pembelajaran mencapai skor rata-rata 4,45 dengan kategori "Sangat Baik", aspek materi mencapai skor rata-rata 4,48 dengan kategori "Sangat Baik", dan aspek media mencapai skor rata-rata 4,42 dengan kategori "Sangat Baik". Sedangkan hasil analisis data pada uji kompetensi/keefektifan menunjukkan bahwa rata-rata skor perolehan 71,33 dan persentase jumlah siswa yang mencapai ketuntasan belajar sebanyak 77\% dengan kategori "Baik". Produk multimedia pembelajaran ini sudah layak menjadi produk akhir untuk disebarluaskan dan diimplementasikan kepada pengguna. Hal ini sesuai dengan target yang ditetapkan peneliti, bahwa kelayakan yang ditetapkan oleh peneliti minimal mendapat nilai " $\mathrm{B}$ " dengan kategori "Baik".

Sebagai produk hasil pengembangan, multimedia pembelajaran matematika yang dikemas dalam bentuk $C D$ interaktif ini juga memiliki beberapa keunggulan dan kelemahan. Keunggulannya adalah: (1) pembuatan $C D$ interaktif ini menggunakan program Macromedia Flash Profesional 8. (2) $C D$ interaktif hasil pengembangan ini dilengkapi dengan sistem "autorun", sehingga untuk menjalankan program cukup memasukkan $C D$ ke dalam $C D$ ROM di komputer maka secara otomatis program akan berjalan. (3) Setiap sub materi dalam $C D$ interaktif hasil pengembangan ini dilengkapi dengan contoh soal dan latihan soal interaktif yang disertai umpan balik.

Disamping keunggulan-keunggulan yang ada, multimedia pembelajaran matemetika hasil pengembangan ini memiliki beberapa kelemahan, yaitu: (1) $C D$ interaktif ini dapat berjalan lancar pada kom- 
puter dengan spesifikasi sekurang-kurangnya Pentium III. (2) Pemilihan jenis musik, jenis huruf, dan jenis warna background belum tentu dapat memenuhi keinginan siswa, karena kesukaan masing-masing siswa berbeda-beda.

\section{Simpulan dan Saran}

Simpulan

Multimedia pembelajaran matematika dengan materi pokok "trigonometri" hasil pengembangan ini dikembangkan menggunakan kaidah-kaidah pengembangan yang meliputi: melakukan analisis, membuat desain dengan mengembangkan flowchart dan menentukan storyboard, membuat produk multimedia pembelajaran, melakukan uji coba dan revisi produk.

Hasil kelayakan multimedia pembelajaran yang dikembangkan sebagai berikut: (1) multimedia pembelajaran matematika hasil pengembangan ditinjau dari aspek pembelajaran, memiliki kualitas termasuk dalam kategori "Sangat Baik"; (2) multimedia pembelajaran matematika hasil pengembangan ditinjau dari aspek materi, memiliki kualitas termasuk dalam kategori "Sangat Baik"; (3) multimedia pembelajaran matematika hasil pengembangan ditinjau dari aspek media, memiliki kualitas termasuk dalam kategori "Sangat Baik".

Hasil belajar siswa setelah menggunakan multimedia pembelajaran matematika hasil pengembangan dan dilanjutkan belajar mandiri, persentase siswa yang mencapai ketuntasan belajar dengan nilai KKM "60"sebanyak $77 \%$ dan termasuk dalam kategori "Baik".

\section{Saran}

Multimedia produk penelitian pengembangan ini dapat disebarluaskan dan dapat digunakan untuk pembelajaran, karena kualitas multimedia ini baik ditinjau dari aspek pembelajaran, aspek materi, dan aspek media.

Perlu dilakukan penelitian lebih lanjut mengenai efektifitas multimedia ini untuk pembelajaran, misalnya dengan penelitian eksperimen atau penelitian tindakan kelas.

\section{Daftar Pustaka}

Agnew, P. W., Kellerman, A. S., \& Meyer, J. M. (1996). Multimedia in the classroom. Massachusetts: A Simon \& Schuster Company.

Ayres, R. (2002). Learner attitudes towards the use of CALL. Journal of Computer Assisted Language Learning, Vol. 15, No. 3, pp. 241-249.

Blackwell, J. (2007). Multimedia applications in education. Diambil pada tanggal 21 Juli 2007 dari http://web.mala. bc.ca/seeds $/ \mathrm{mm} /$ \#Introduction

Borg, W. R. \& Gall, M. D. (1983). Educational research: An introduction. Fourth edition. New York: Longman Inc.

Budiningsih, C. A. (2005). Belajar dan pembelajaran. Jakarta: PT Rineka Cipta.

Daniamiseno, A.G. (2004). Peranan teknologi pembelajaran dalam proses belajarmengajar ilmu pengetahuan sosial. Pidato Pengukuhan Guru Besar di depan Rapat Senat Terbuka di Universitas Negeri Yogyakarta pada tanggal 2 Oktober 2004.

Depdiknas. (2006). Standar kompetensi dan kompetensi dasar. Jakarta: Depdiknas

Hackbarth, S. (1996). The educational technology handbook. Englewood Cliffs, New Jersey: Educational Technology Publications Inc.

Jenks, M. S. \& Springer, J. M. (2005). A view of the research of efficacy of CAI. electronic journal for the integration of technology in education vol 1 no.2. Diambil pada tanggal 28 September 2005 dari http://ejite.isu.edu/ Volume1No2/Jenks.pdf

Kulik, Bangert, \& Williams (2002). Electronic journal for the integration of 
technology in education Vol. 1 No. 2. Diambil tanggal 19 Agustus 2007 dari http://ejite.isu.edu/Volume 1 No. 2/jenks.pdf.htm

Newby T.J., Stepich D.A., Lehman J.D., \& Russell J.D. (200). Instructional technology for teaching and learning. Upper Saddle River, New Jersey: Prentice-Hall Inc.

Oetomo, B.S.D. (2002). E-education. Konsep teknologi dan aplikasi internet pendidikan. Yogyakarta: Andi.

Priyanto, D. (2009). Pengembangan multimedia pembelajaran berbasis komputer. Jurnal pemikiran alternatif pendidikan. Insani/Vol 14/No 1/JanApr 2009-110.

Seels, B. B. \& Richey, R. C. (1994). Instructional technology : The definition and domains of the field. Washington, DC: AECT.

Sukardjo. (2005). Evaluasi pembelajaran. Diktat Mata Kuliah Evaluasi Pembelajaran. Yogyakarta: Prodi TP PPs UNY. Tidak Diterbitkan.

Vaughan, R., Multimedia: What it is and what it can do for our students. Diambil tanggal 15 Juni 2010 dari http: //jaltcall.org/cjo/5_00/vaughan.ht $\underline{\mathrm{ml}}$.

Woolf, B. \& Hall, W. (2005). Interactive multimedia systems for teaching and learning. Diambil tanggal 20 September 2005 dari http://ckc.cs. umass.edu/ckc/ publications/ multimedia_pedagogues.pdf 